\title{
Response of ectopic prostatic ACTH production to metyrapone
}

\author{
B. N. Statham \\ M.B., M.R.C.P. (U.K.)
}

\author{
T. H. PARdoe \\ M.B., B.Ch.
}

\author{
M. A. MIR \\ M.B., M.R.C.P. \\ Department of Medicine, C2 Unit, Welsh National School of Medicine
}

\begin{abstract}
Summary
A case of ectopic prostatic ACTH production exhibiting a good response to metyrapone is reported.

\section{Introduction}

Ectopic hormone production is a rarely recognized complication of prostatic carcinoma. Only 3 well documented cases of adrenocorticotrophin production have been reported (Ewark, Oluhy and Bennett, 1973; Lovern, Farriss and Wettlanfer, 1975; Wenk, Bhagauan and Levy, 1977).
\end{abstract}

\section{Case report}

A 63-year-old man who 3 years previously had undergone a transurethral prostatic resection for adenocarcinoma presented with a 2-month history of 'euphoric' behaviour followed by an excessive thirst and ankle swelling. He was a non-smoker and had been taking ethinyl oestradiol (stilboestrol) $3 \mathrm{mg}$ daily since the prostatic resection. Initial examination revealed an extravagant and extrovert personality in a man previously described as shy. There was no abnormal pigmentation, he was normotensive and had gross bilateral below knee oedema. Investigations revealed impaired renal function and a hypokalaemic alkalosis (serum sodium $157 \mathrm{mmol} / 1$; potassium $1.7 \mathrm{mmol} / 1$; bicarbonate $32.0 \mathrm{mmol} / 1$; urea $14.5 \mathrm{mmol} / \mathrm{l}$ ); an elevated random plasma glucose at $8.4 \mathrm{mmol} / \mathrm{l}$ and a normochromic normocytic anaemia (Hb $12.0 \mathrm{~g} / \mathrm{dl})$. X-rays of the chest and skull showed no abnormality. Prostatic acid phosphatase was 5 i.u./1 (0-4 i.u./l). Renal tubular function was normal as demonstrated by a normal urinary acidification test and a normal urinary amino acid composition. Plasma cortisol was markedly elevated at $>1377 \mathrm{nmol} / \mathrm{l}$ (n.r. $<800$ $\mathrm{nmol} / \mathrm{l})$ as was adrenocorticotrophic hormone (ACTH) at $1589 \mathrm{ng} / \mathrm{l}($ n.r. $<80 \mathrm{ng} / \mathrm{l})$.

A dexamethasone suppression test was not performed in view of steady deterioration in mental function and ankle oedema increasingly resistant to diuretic therapy. Metyrapone was then commenced in a dose of $750 \mathrm{mg}$ every $6 \mathrm{hr}$, together with prednisolone $(15 \mathrm{mg} /$ day) to prevent a possible Addisonian crisis. Within 3 days the requirements of potassium supplements declined from $26 \mathrm{~g}$ of potassium chloride daily to $5 \mathrm{~g}$ /day and his mental state gradually improved. Serum cortisol levels returned to the normal range $(359 \mathrm{nmol} / \mathrm{l})$. At this stage there was no evidence of metastatic disease and prolonged survival seemed a possibility.

In view of this, an orchidectomy was uneventfully performed in an attempt to suppress tumour growth. The patient was then discharged home in good health taking metyrapone $750 \mathrm{mg} 6$ hourly and amiloride $10 \mathrm{mg}$ daily. Two months later he was readmitted with rapidly worsening renal failure and died within $48 \mathrm{hr}$ of admission. A post-mortem examination revealed a poorly differentiated prostatic adenocarcinoma with multiple liver, lung and skeletal secondary deposits, the adrenal glands were hypertrophied (total weight $31 \mathrm{~g}$ ).

\section{Discussion}

This case illustrates several features typical of the previously reported cases of prostatic ectopic ACTH production; the 3-year time lag from the initial diagnosis of a prostatic tumour to the presentation of ectopic ACTH production; the oedema, the hypokalaemic alkalosis and raised plasma glucose have all been reported in previous cases as has the histological picture of an undifferentiated or adenocarcinoma. The response to metyrapone in such a rewarding manner has not previously been noted and bilateral adrenalectomy with its many inherent dangers is the only treatment to have produced an overall survival of 3 months as in this case.

Metyrapone acts as an inhibitor of the $11 \beta$ hydroxylation step necessary for synthesis of glucocorticoids within the adrenal glands, hence its more 
common usage as a test of the pituitary-adrenal axis. Common side effects include nausea and vomiting, this has tended to restrict its usefulness both as a diagnostic and a therapeutic manoeuvre. In this case, however, metyrapone was well tolerated and produced a gratifying response for both the patient and his family in a condition for which the long term outlook remains very poor.

\section{References}

Ewark, S.R., Oluhy, R.G. \& Bennett, A.H. (1970) Ectopic adrenocorticotrophin syndrome with prostatic carcinoma. Urology, 2, 666.

LOVERN, W.S., FARRISS, B.L. \& WeTtLANFER, J.N. (197 Ectopic ACTH production in disseminated prostate adenocarcinoma. Urology, 5, 817.

Wenk, R.E., Bhagauan, B.S. \& Levy, R. (1977) Ectopece ACTH, prostatic oat cell carcinoma and marked hype natremia. Cancer, 40, 773. 